\section{幽闹 Digital Commons@}

Loyola Marymount University

LMU Loyola Law School
Loyola of Los Angeles International and Comparative Law Review

3-1-2006

\title{
An Introduction to Self-Incrimination in Jewish Law, with Application to the American Legal System: A Psychological and Philosophical Analysis
}

Samuel J. Levine

Follow this and additional works at: https://digitalcommons.Imu.edu/ilr

Part of the Law Commons

\section{Recommended Citation}

Samuel J. Levine, An Introduction to Self-Incrimination in Jewish Law, with Application to the American Legal System: A Psychological and Philosophical Analysis, 28 Loy. L.A. Int'l \& Comp. L. Rev. 257 (2006). Available at: https://digitalcommons.Imu.edu/ilr/vol28/iss2/2

This Article is brought to you for free and open access by the Law Reviews at Digital Commons @ Loyola Marymount University and Loyola Law School. It has been accepted for inclusion in Loyola of Los Angeles International and Comparative Law Review by an authorized administrator of Digital Commons@Loyola Marymount University and Loyola Law School. For more information, please contact digitalcommons@lmu.edu. 


\title{
An Introduction to Self-Incrimination in Jewish Law, With Application to the American Legal System: A Psychological and Philosophical Analysis
}

\author{
SAMUEL J. LEVINE*
}

\section{INTRODUCTION}

Law serves a central role in Jewish faith and tradition. Indeed, Jewish law comprises a legal system which developed over thousands of years, exploring and regulating every form of human endeavor and experience.' Thus, it may be unsurprising that

- Associate Professor of Law, Pepperdine University School of Law; LL.M., Columbia University; J.D., Fordham University; Ordination, Yeshiva University; B.A., Yeshiva University.

This Essay expands on my contribution to a forthcoming book, VIEWING LAW THROUGH THE EYES OF FAITH, edited by my colleague Bob Cochran, and consisting of papers based on presentations delivered at the 2002 Conference of Religiously Affiliated Law Schools that Bob organized at Pepperdine University School of Law. The Essay also builds on my remarks at both the 2004 Conference of Religiously Affiliated Law Schools that Jack Pratt organized at Notre Dame Law School and the program of the Section on Law and Religion that Frank Ravitch organized at the 2005 Annual Meeting of the Association of American Law Schools. I thank Bob, Jack, and Frank for inviting me to participate at the respective conferences, I thank Rick Garnett and Tom Shaffer for encouraging me further to develop these thoughts, and I thank Joshua Dressler for helpful comments. I thank Emily Peacock, Pepperdine University School of Law, Class of 2005, for research assistance. Finally, I thank Fraida Liba, Yehudah, Aryeh, and Rachel for their continued encouragement.

1. See, e.g., ARYeh Kaplan, The Handbook OF Jewish Thought 78 (1979) (stating that the commandments "penetrate every nook and cranny of a person's existence, hallowing even the lowliest acts and elevating them to a service to God" and that "the multitude of laws governing even such mundane acts as eating, drinking, dressing and business, sanctify every facet of life, and constantly remind one of [one's] responsibilities toward God"). See also Moshe Silberg, Law and Morals in Jewish Jurisprudence, 75 HARV. L. REV. 306, 322 (1961) ("The . . mode of dress, . . diet, dwelling, behavior, relation with [others], .. .family affairs, and ... business affairs were all prefixed and premolded, in a national cloak, in a set of laws that was clear, severe, strict, detailed, that accompanied [an individual] day by day, from cradle to grave."). See infra 
American courts and legal scholars have increasingly turned to Jewish legal tradition for insights into various issues confronting the American legal system. ${ }^{2}$ Jewish law has provided an alternative model and, at times, a contrast case that some have found particularly helpful in illuminating complex, controversial, and unsettled areas of American law. ${ }^{3}$

In light of these developments, this Essay aims to consider the efficacy of drawing on Jewish law to facilitate a more thoughtful analysis of issues in American law, with a specific focus on the issue of self-incrimination. The Essay begins with a brief description of the function of Jewish law within Jewish faith and tradition. Employing a psychological and philosophical framework, the Essay then explores the issue of self-incrimination in Jewish law, both on its own terms and through an analysis of its potential relevance to difficult questions regarding the use of criminal confessions in the United States. ${ }^{4}$ The Essay concludes

notes 10-13 and accompanying text.

2. See, e.g., Daniel G. Ashburn, Appealing to a Higher Authority?: Jewish Law in American Judicial Opinions, 71 U. DET. MERCY L. REV. 295, 298-99, 301, 303, 307, 310-13 (1994); Chad Baruch \& Karsten Lokken, Research of Jewish Law Issues: A Basic Guide and Bibliography for Students and Practitioners, 77 U. DET. MERCY L. REV. 303-304 (2000); Samuel J. Levine, Jewish Legal Theory and American Constitutional Theory: Some Comparisons and Contrasts, 24 HASTINGS CONST. L.Q. 441-42, 444 (1997) [hereinafter Levine, Jewish Legal Theory]; Samuel J. Levine, Teaching Jewish Law in American Law Schools-Part II: An Annotated Syllabus, 2 CHI.-KENT J. INT'L \& COMP. L. 1 (2002); Samuel J. Levine, Teaching Jewish Law in American Law Schools: An Emerging Development in Law and Religion, 26 FORDHAM URB. L.J. 1041, 1042 (1999); Suzanne Last Stone, In Pursuit of the Counter-Text: The Turn to the Jewish Legal Model in Contemporary American Legal Theory, 106 HARV. L. REV. 813, 814 (1993).

3. See supra note 2 .

4. An examination of self-incrimination may be particularly instructive, as it involves an area of law in which American courts and scholars alike have relied upon the Jewish legal system to analyze and interpret American legal principles. A substantial body of American case law and scholarship has referred to the Jewish law of self-incrimination.

The list of such cases includes: Garrity v. State of New Jersey, 385 U.S. 493, $497-8 \mathrm{n} .5$ (1967); Miranda v. Arizona, 384 U.S. 436, 458 n.27 (1966); In re Agosto, 553 F. Supp. 1298, 1300 (D. Nev. 1983); Moses v. Allard, 779 F. Supp. 857, 870 (E.D. Mich. 1991); People v. Brown, 86 Misc. 2d 339, 487 n.5 (Nassau County Ct. 1975); Roberts v. Madigan, 702 F. Supp. 1505, 1517 n.20 (D. Colo. 1989); State v. McCloskey, 446 A.2d. 1201, 1208 n.4 (N.J. 1982); U.S. v. Gecas, 120 F.3d 1419, 1425 (11th Cir. 1997); U.S. v. Huss, 482 F.2d. 38, 51 (2d Cir. 1973).

The list of scholarship includes: LEONARD W. LEVY, ORIGINS OF THE FIFTH AMENDMENT: THE RIGHT AGAINST SELF-INCRIMINATION 433-441 (1968); Albert W. Alschuler, A Peculiar Privilege in Historical Perspective: The Right to Remain Silent, in THE PRIVILEGE AGAINST SELF-INCRIMINATION: ITS ORIGINS AND DEVELOPMENT 181, 279 n.28 (1997); Isaac Braz, The Privilege Against Self-Incrimination in Anglo-American Law: The Influence of Jewish Law, in JEWISH LAW AND CURRENT LEGAL PROBLEMS 
with the cautious proposition that the American law of selfincrimination may benefit from incorporating some of the insights offered by Jewish legal thought.

161-168 (Nahum Rakover ed., 1984); Malvina Halberstam, The Rationale for Excluding Incriminating Statements: U.S. Law Compared to Ancient Jewish Law, in JEWISH LAW AND CURRENT Legal Problems, supra 4, at 177; George Horowitz, The Privilege Against Self-Incrimination-How Did It Originate?, 31 TEMPLE L.Q. 121, 125 (1958); Simcha Mandelbaum, The Privilege Against Self-Incrimination in Anglo-American and Jewish Law, 5 AM. J. COMP. L. 115, 116-118 (1956); Irene Merker Rosenberg \& Yale L. Rosenberg, In the Beginning: The Talmudic Rule Against Self-Incrimination, 63 N.Y.U. L. REV. 955, 955 (1988); Bernard Susser, Worthless Confessions: The Torah Approach, 130 NEw L.J. 1056 (1980); Cheryl G. Bader, "Forgive me Victim for I Have Sinned": Why Repentance and the Criminal Justice System Do Not Mix-A Lesson From Jewish Law, 31 FORDHAM URB. L.J. 69, 88 (2003); Suzanne Darrow-Kleinhaus, The Talmudic Rule Against Self-Incrimination and the American Exclusionary Rule: A Societal Prohibition Versus an Affirmative Individual Right, 21 N.Y. L. SCH. J. INT'L \& COMP. L. 205, 206-7 passim (2002); Michelle M. Sharoni, A Journey of Two Countries: A Comparative Study of the Death Penalty in Israel and South Africa, 24 HASTINGS INT'L \& COMP. L. REV. 257, 263 (2001); Daniel J. Seidmann \& Alex Stein, The Right to Silence Helps the Innocent: A Game Theoretic Analysis of the Fifth Amendment Privilege, 114 HARV. L. REV. 431, 452 n.70 (2000); Erica Smith-Klocek, Note, A Halachic Perspective on the Parent-Child Privilege, 39 CATH. LAw. 105, 109 (1999); Gregory Thomas Stremers, The SelfIncrimination Clause and the Threat of Foreign Prosecution in Bankruptcy Proceedings: A Comment on Moses v. Allard, 70 U. DET. MERCY L. REV. 847, 854-55 (1993); Debra Ciardiello, Seeking Refuge in the Fifth Amendment: The Applicability of the Privilege Against Self-Incrimination to Individuals Who Risk Incrimination Outside the United States, 15 FORDHAM INT'L L.J. 722, 725 (1992); Aaron M. Schreiber, The Jurisprudence of Dealing with Unsatisfactory Fundamental Law: A Comparative Glance at the Different Approaches in Medieval Criminal Law, Jewish Law and the United States Supreme Court, 11 PACE L. REV. 535, 550 (1991).

Although in a number of cases and works the references to Jewish law are fairly brief and tangential, others demonstrate the significance that has been accorded Jewish law in consideration of the American rule of self-incrimination. For example, in Miranda $v$. Arizona, the landmark United States Supreme Court case defining the contours of the constitutional privilege against self-incrimination, Chief Justice Warren's majority opinion cited a reference to Jewish law. Miranda, 384 U.S. 436, at 458, n.27 (1966). Moreover, Leonard Levy closes his groundbreaking historical study of the origins of the privilege with an Appendix entitled "Talmudic Law," stating that "[n]o description of the origins of the right against self-incrimination would be complete without acknowledgment of the existence of the right in ancient Jewish law." See LEVY, supra 4, at 433-41. Finally, in his Introduction to Professor Aaron Kirschenbaum's exhaustive study of self-incrimination in Jewish law, Arthur J. Goldberg, a former justice of the United States Supreme Court, writes that "[w]e have something to learn from this ancient tradition, particularly now, when our constitutional privilege against self-incrimination, embodied in the Fifth Amendment, is under attack." Arthur J. Goldberg, Introduction, in AARON KIRSCHENBAUM, SELF-INCRIMINATION IN JEWISH LAW viii-ix (1970). 


\section{II.A BRIEF LOOK AT THE ROLE OF LAW IN JEWISH FAITH AND TRADITION}

It would seem difficult to overstate the importance of Jewish law, or halacha, in Jewish faith and tradition. This is the case particularly for those who appreciate the Torah as divinely authored and immutable. Describing halacha as "central" or "essential" does not capture the extent of the significance that Jewish thought attaches to the letter and the spirit of the law. The Torah and Midrashic exegesis dramatically depict the Revelation at Sinai and the giving of the law as both the formative moment of the Nation of Israel and the basis of the Nation's relationship with God. ${ }^{5}$

Moreover, study of the law is viewed as a powerful means of connecting with God on both intellectual and spiritual levels. As the halacha is of divine origin, it serves as a primary source for understanding God's will, God's ways, and God's wisdom. ${ }^{6}$ Indeed, God's law provides a unique avenue for relating to the reality of God's world.' The Talmud states strikingly that, since the

5. See, e.g., ABRAHAM R. BESDIN, 1 REFlections OF THE RAV: LESSONS IN JEWISH THOUGHT, ADAPTED FROM LECTURES OF RABBI JOSEPH B. SOLOVEITCHIK 8998 (2d Rev. ed. 1993); KAPLAN, supra note 1, at 53-58; ElIYAHU KITOV, 2 THE BOOK OF OUR HERIT AGE 265-69 (Nathan Bulman trans., 1978) (originally published in Hebrew as SefER Ha-Toda'aH (1976)). See also Rabbi AHARON Lichtenstein, 2 Leaves of FAITH: THE WORLD OF JEWISH LEARNING 227 (2004):

It was ... at Sinai ... that [the Nation of Israel] attained mature national fruition; and it was there that two new related elements, henceforth cardinal Jewish values, entered the picture. The first was Torah, the content of revelation proper, whose study and perpetuation then became a central Jewish concern. The second was Israel, a covenantal community forged by axiological commitment no less than by historical destiny ....

6. See RABbi HeRshel SCHACHTER, ERETZ HATZEVI: BE'UREI SUGYOT 1-2 (1992).

It may be instructive to quote at length the words of Rabbi Aharon Lichtenstein:

[The study of the law offers] insight, as direct and profound as [a human] is privileged to attain, into the revealed will of [the] Creator ... an opportunity to get (salve reverentia) a first-hand knowledge of the divine will, to deepen and broaden our minute understanding of God's infinite reason. In its essence, the Torah-particularly the Hala[c]ha-constitutes an immanent expression of God's transcendent rational will. By studying its texts, analyzing its principles, and developing its ideas, we are able to approach, however haltingly, that unattainable goal toward which [Moses] strove so desperately... "Let me know Thy ways."

AhaRon LiChtenstein, 1 LEAVES OF FAITH: THE WORLd OF JEWISH LEARNING 91 (2003) (quoting Exodus 33:13).

7. As Rabbi Joseph Soloveitchik describes in extensive detail:

[T] he essence of the Hala[c]ha[], which was received from God, consists in 
destruction of the Temple in Jerusalem, God's "place" in the world is found in the halacha and its application. ${ }^{8}$ Thus, exploring the law in pursuit of the divine comprises an inherently profound and spiritually transforming experience.

In addition to the cognitive and spiritual significance of the law, as the Hebrew term implies, halacha offers a way of life-a path for all of life's endeavors and activities. ${ }^{10}$ The substance of

creating an ideal world and recognizing the relationship between that ideal world and our concrete environment in all its visible manifestations and underlying structures. There is no phenomenon, entity or object in this concrete world which the a priori Hala[c]ha[] does not approach with its ideal standard.

RABBI JOSEPH B. SOLOVEITCHIK, HALAKHIC MAN 19-20 (Lawrence Kaplan trans., 1983) (originally published in Hebrew as ISH HA-HALAKHAH, in 1 Talpiot 3-4 (1944)).

8. See The Babylonian TAlmud, Berakoth 8a. See also RabBi YITZCHAK HUTNER, PACHAD YiTzCHAK: CHANUKA 63-75 (1998).

9. Again, in the words of Rabbi Lichtenstein:

Torah study, when properly pursued, affects our total spiritual personality. Partly because it does afford us a better insight into inscrutable divine wisdom, and partly because it engages the mind-and with it the whole [person]-in pursuit of religious knowledge, it transmutes our innermost being. The knowledge we can acquire of God's will increases our conscious, and subconscious, awareness of [God]; the very act of weighing [God's] words or of analyzing [God's] laws draws us imperceptibly nearer to [God] and to them.... Torah study leaves an indelible imprint upon our total personality and, in the process, transforms it. ... Torah study becomes the premier agent in effecting a gradual spiritual regeneration. Paradoxically, through a constant reciprocal process, it both sustains piety and is sustained by it. Keener study leads to greater piety, and more fervent devotion leads to profounder knowledge.

LICHTENSTEIN, supra note 6, at 91-92. Cf. RABBI CHAIM OF VOLOZHIN, NEFESH HACHAIM, Section 4; SOLOVEITCHIK, supra note 7, at 87 ("The cognition of the Torahthis is the holiest and most exalted type of service. ... The study of the Torah is not a means to another end, but is the end point of all desires. It is the most fundamental principle of all.").

10. See LICHTENSTEIN, supra note 5, at 341-42 (describing the "concept of normative existence, of a life governed by divinely ordained law and organized as an all-embracing religious discipline" and stating that through the Halacha a person's "whole life is permeated by an awareness of [one's] relation to God"; that "[i]n every sphere of endeavor-be it social or economic, physical or intellectual-conscious choice and religious response are operative"; and that "the Halacha, through its numerous laws concerning various areas, directs... the sanctification of [self] and ... environment[ ,] suffus[ing] ... life with spiritual significance, and integrat[ing] ... activity into a divinely ordered whole"). See also Samuel J. Levine, Halacha and Aggada: Translating Robert Cover's Nomos and Narrative, 1998 UTAH L. REV. 465, 484 (1998):

[T] he Hebrew term "halacha," though implying a legal order and often used to denote "Jewish religious law," suggests a broader range of ideas than those included in legal rules. A more literal translation of "halacha" would evoke a "path" of life; to inhabit the halacha is, by definition, to live in it. Thus, the halacha truly provides a "world-view" through which all of the world and life's experiences are perceived. Moreover, as a path of life, halacha incorporates those aspects of normative life that complement the legal precepts, the aggada. 
halacha extends far beyond the "rituals" of Jewish "religious" practice. In the words of Rabbi Joseph B. Soloveitchik, a leading contemporary scholar of Jewish law, "[t]here is no phenomenon, entity, or object in this concrete world" beyond the grasp of halacha. ${ }^{11}$ For example, he notes, "just a few of the multitude of hala[c]hic subjects" include: "sociological creations: the state, society, and the relationship of individuals within a communal context"; "laws of business, torts, neighbors, plaintiff and defendant, creditor and debtor, partners, agents, workers, artisans, bailees"; "[f]amily life"; "[w]ar, the high court, courts and penalties they impose"; and "psychological problems." "Thus, the foundational and authoritative texts of Jewish law-from the Torah and the Talmud to commentaries, codifications and responsa-contain prescriptions for ethical conduct and moral behavior in public and private, and in both worship and more worldly activities. ${ }^{13}$

Moreover, lending even further depth to halacha, the law has developed over the course of thousands of years in numerous and disparate societal and geographical settings, under both benign and, all-too-often, belligerent and oppressive circumstances. Consequently, the law continuously confronted countless varieties of previously unaddressed issues demanding consideration and normative resolution. ${ }^{14}$ Through a careful combination of fidelity to the past and, when necessary, innovation and creativity, legal

11. SOLOVEITCHIK, supra note 7 , at 20.

12. Id. at 22. See also Samuel J. Levine, Taking Ethics Codes Seriously: Broad Ethics Provisions and Unenumerated Ethical Obligations in a Comparative Hermeneutic Framework, 77 TULANE L. REV. 527, 542-43 n.56 (2003) (citing sources for the proposition that "[s]cholars of Jewish law identify 613 commandments enumerated in the Torah, covering nearly every area of human activity"; that "[i]n addition, many of these commandments can further be divided into component parts, resulting in a substantially larger number of enumerated obligations"; and that "there exist other imperatives that, although for methodological reasons are not tallied as commandments, nonetheless present yet additional enumerated obligations").

13. See Samuel J. Levine, Reflections on the Practice of Law as a Religious Calling, From a Perspective of Jewish Law and Ethics, 32 PEPP. L. REV. 411, 412 (2005); Samuel J. Levine, The Broad Life of the Jewish Lawyer: Integrating Spirituality, Scholarship, and Profession, 27 TEX. TECH L. REV. 1199, 1199 (1996).

14. See, e.g., Michael Broyde \& Howard Jachter, Electrically Produced Fire or Light in Positive Commandments, 25 J. HALACHA \& CONTEMP. SOC'Y 89, 125-6 (1993); Michael Broyde \& Howard Jachter, The Use of Electricity on Shabbat and Yom Tov, $21 \mathrm{~J}$. HALACHA \& CONTEMP. SOC'Y 4 (1991); Arthur Schaffer, The History of Horseradish as a Bitter Herb on Passover, 8 GESHER 217 (1981); AdIN STEINSALTZ, THE ESSENTIAL TALMUD 234-38 (Chaya Galai trans., 1976). 
authorities have responded to these challenges by applying settled and known legal principles to resolve the questions accompanying new and unanticipated circumstances. ${ }^{15}$

Acknowledging the range and depth of the Jewish legal system, contemporary American courts and scholars have turned to Jewish law for insights into numerous substantive and theoretical issues. American judicial opinions and law review articles have relied upon substantive parallels in the two legal systems in areas such as criminal law and procedure, family law, torts, property, evidence, ethics, commercial law, and health law. ${ }^{16}$ Somewhat more ambitiously and perhaps even more effectively, some scholars have looked at the conceptual underpinnings of various aspects of Jewish law and Jewish legal theory to illuminate not only substantive issues in American law but also some of the more complex and theoretical issues prevalent in American legal scholarship. ${ }^{17}$ Of course, the two legal systems are premised upon fundamentally different assumptions: one based self-consciously on religion and the other requiring a more generally accessible rationale for legal decisions. Thus, Jewish law and American law sometimes produce radically different responses to similar legal questions. Nevertheless, the two systems share significant conceptual similarities, which allows careful and productive analytical comparison. ${ }^{18}$

To illustrate the possible application of halacha in the analysis of the American legal system, it may be instructive to examine a specific issue of significance in American law through the lens of Jewish law. American courts and scholars face important

15. See RabBi Hershel Schachter, B'IKVEI Hatzoan 1-3 (1997). See also Levine, Jewish Legal Theory, supra note 2, at 453-57; Samuel J. Levine, An Introduction to Legislation in Jewish Law, with References to the American Legal System, 29 SETON HALL L. REV. 916, 932-35 (1998) (discussing modification of Rabbinic legislation as a result of changed circumstances).

16. See supra note 2 .

17. See id.

18. For differing views on the efficacy of such comparative analysis, compare Samuel J. Levine, Capital Punishment in Jewish Law and Its Application to the American Legal System: A Conceptual Overview, 29 ST. MARY'S L.J. 1037, 1037-38 n.2 (1998) (citing, as examples of scholarship endorsing such application, David R. Dow, Constitutional Midrash: The Rabbis' Solution to Professor Bickel's Problem, 29 Hous. L. REV. 543, 544 (1992); Irene Merker Rosenberg \& Yale L. Rosenberg, Guilt: Henry Friendly Meets the Maharal of Prague, $90 \mathrm{MICH}$. L. REV. 604, 614-15 (1991)), with Levine, supra at $1038 \mathrm{n} .3$ (citing, as examples of scholarship expressing a more cautious approach, Steven F. Friedell, Book Review: Aaron Kirschenbaum on Equity in Jewish Law, 1993 BYU L. REV. 909, 919 (1993); Stone, supra note 2, at 893-94). See also infra note 64. 
challenges with the issue of self-incrimination, while the Jewish legal system has addressed the issue since ancient times. In fact, it is not uncommon for both American courts and American legal scholars to refer to and rely on the treatment of self-incrimination in Jewish law. ${ }^{19}$ Therefore, a discussion about self-incrimination may serve as a particularly helpful model for a broader understanding of the role of law in Jewish faith and tradition as well as a consideration of conceptual comparisons between the Jewish legal system and the American legal system.

\section{III.SELF-INCRIMINATION IN JEWISH LAW: A PSYCHOLOGICAL AND PHILOSOPHICAL ANALYSIS}

The rule concerning self-incrimination in Jewish law may be summarized quite succinctly: an individual may not be punished on the basis of self-incriminatory statements. ${ }^{20}$ Although the precise nature of the rule has been the subject of detailed discussion and debate from Talmudic times to the present, ${ }^{21}$ there is universal agreement among sources and authorities in Jewish law accepting a general rule precluding punitive confessions. ${ }^{22}$ Moreover, as this rule is not subject to dispute, its categorical application operates independent of attempts to ascribe or ascertain a divine rationale for the rule. ${ }^{23}$ Indeed, as Jewish law is understood to reflect God's divine will and wisdom, it is not uncommon for legal authorities and philosophers of Jewish law to consider the law on two different planes. On a practical level, for halacha to function, a systematic application of the law requires derivation and

19. See sources cited supra note 4 .

20. See, e.g., THE Babylonian TAlmud, Sanhedrin 9b; MAIMONIDES, Laws of Sanhedrin 18:6, in MISHNE TORAH (Abraham M. Hershman trans., Yale Univ. Press 1949). See also MAIMONIDES, Laws of Eduth 12:2, in MISHNE TORAH, supra.

21. For works in English analyzing Talmudic and post-Talmudic sources addressing the issue of self-incrimination, see KIRSCHENBAUM, supra note 4, at 34-92; Arnold Enker, Self-Incrimination in Jewish Law-A Review Essay, 4 DINÉ ISRAEL cvii (1973) (reviewing KiRSCHENBAUM, supra); Rosenberg \& Rosenberg, supra note 4, at 984-1041.

22. Professor Kirschenbaum has identified Rabbi Solomon ben Simeon Duran [Rashbash], an Algerian fifteenth century rabbi, as "to the best of my knowledge, the only Jewish authority who disagrees with the general interpretation of the rabbinic law against criminal confessions." KIRSCHENBAUM, supra note 4, at 68 . After carefully analyzing the position set forth by Rashbash, Kirschenbaum responds dismissively, concluding that Rashbash "is not only alone in his opinion on self-incrimination. His proof-texts are not convincing, and the weight of the traditional evidence is in direct opposition to him. No later authority takes up his position, and no later decision follows his line of reasoning." Id. at 72 .

23. See MAIMONIDES, Laws of Sanhedrin 18:6, in MISHNE TORAH, supra note 20. 
delineation of the substance of the law and its interpretation under various circumstances and conditions. Though neither superficial nor overly formalistic, this level of understanding often addresses primarily the mechanics of the law, without necessitating an investigation into the divine rationale behind the law. As some have put it, this enterprise emphasizes the "what" rather than the "why." 24 In the area of ritual law in particular, legal interpretation and application, though often complex, generally depend upon defining the law and its parameters rather than on attempting to identify the divine wisdom reflected in the ritual commandment. ${ }^{25}$ Likewise, legal authorities interpret and apply the substance of the rule against self-incrimination largely independent of any reasoning that may be offered as a logical basis for the rule. ${ }^{26}$

On a more theoretical level, however, philosophers of Jewish law often look beyond the mechanics of the law and attempt to glean the divine wisdom present in legal rules. ${ }^{27}$ Indeed, Maimonides, one of the most influential Medieval legal authorities and philosophers, dedicates a substantial portion of Moreh Hanevuchim, his philosophical magnum opus, to uncovering divine reasoning for ostensibly arational Biblical laws. ${ }^{28}$ Such an endeavor

24. See LiChtensteIn, supra note 6, at 194. See also ABRAHAM R. BeSDIN, 2 REFLECTIONS OF THE RAV: MAN OF FAITH IN THE MODERN WORLD, ADAPTED FROM LECTURES OF RABBI JOSEPH B. SOLOVEITCHIK 91-99 (1989); JOSEPH B. SOLOVEITCHIK, THE HALAKHIC MIND: AN ESSAY ON JEWISH TRADITION AND MODERN THOUGHT 94 (1986).

25. See Levine, Jewish Legal Theory, supra note 2, at 458-61; SCHACHTER, supra note 6 , at 135 .

26. Cf. Rosenberg \& Rosenberg, supra note 4, at 1027 n.256 (stating that "[a]t the risk of oversimplification, the traditional view is that Jewish law embodies an absolute prohibition against the use of confessions in criminal and quasi-criminal cases because God has so decreed" but adding that "... [f]aith does not, however, preclude intellectual grappling with such issues").

27. See BESDIN, supra note 24 , at $91-92$ ("[O]ne may distinguish between motivations, explanations, and interpretations. Ascribing Divine motivations is a hopeless exercise; explaining how the ritual achieves its purpose is a futile enterprise. But offering a subjective interpretation which will strengthen its spiritual meaning for the worshipper is not only permissible, but should even be encouraged."); see also id. at 98 ("Accepting [commandments] ... with pious obedience is meritorious, but ascribing an interpretive meaning, heightens the spiritual experience... engaging us both intellectually and emotionally in the worship of God").

See also BESDIN, supra note 5, at 91-99; YITZCHAK HEINEMANN, TA'AMEI HAMITZVOT BESAFRUT YISRAEL (1954); DAVID NOVAK, NATURAL LAW IN JUDAISM $62-$ 91 (1998); SOLOVEITCHIK, supra note 24, at 91-99. See generally Samuel J. Levine, Ours to Reason Why: The Quest for Ta'amei HaMitzvot, HAMEVASER 7 (May 1990).

28. See MAIMONIDES, MOREH HANEVUChIM [GuIDE Of THE PERPLEXEd], Section 3 (Univ. of Chicago Press 1963); SOLOVEITCHIK, supra note 24, at $91-92$ (declaring that 
requires not only a healthy dose of ambition, sufficient to motivate pursuit of the divine rationale behind the law, but also an appropriate measure of humility, allowing for the acknowledgment that ultimately, God's reasoning remains unknowable to humans. ${ }^{29}$ In the context of the rule against self-incrimination, attempts to identify a divine rationale have produced a variety of penetrating insights into the law. ${ }^{30}$

In the Mishne Torah, Maimonides' monumental codification of the entire corpus of Jewish law, the discussion of selfincrimination is comprised of a two-tiered analysis. ${ }^{31}$ Maimonides first introduces the rule against self-incrimination as a "scriptural decree. ${ }^{32}$ In an apparent reference to Biblical verses ${ }^{33}$ he writes that capital or corporal punishment may be implemented based only upon the testimony of two witnesses. ${ }^{34}$ Although divine decree is, by definition, binding and authoritative without need for further justification, Maimonides nevertheless suggests a rationale for the law..$^{35}$ According to Maimonides, confessions may not serve

"[o]ne of the most perplexing problems" in Jewish philosophy "is that of the rationalization for the commandments" and observing that "[t]wenty-five chapters of the Guide [for the Perplexed] are devoted exclusively to the solution of this problem"). See also BESDIN, supra note 24, at 101 (citing the writings of Maimonides in the Mishne Torah in support of the proposition that "even as we perform rituals in accordance with God's will, whose reasons are inscrutable, we may ascribe interpretations in order to give meaning to our spiritual experience").

29. "The attempt to discover a rationale for [commandments] is generally considered a noble pursuit. For example, Maimonides writes that it is proper to contemplate the [commandments] and if possible to suggest reasons for them." Levine, Jewish Legal Theory, supra note 2, at $459 \mathrm{n} .104$ (quoting MAIMONIDES, supra note 20, Laws of Temurah 4:13). "Nevertheless, Maimonides stresses that if an individual is unable to discover a rationale for a particular [commandment], he or she should recognize that there is still a Divine rationale for it." Id. (quoting MAIMONIDES, supra note 20, Laws of Me'ilah 8:8).

30. See Haim H. Cohn, Privilege Against Self-Incrimination: Israel, 51 J. CRIM. L. CRIMINOLOGY \& POLICE SCI. 175, 177-78 (1960); Rosenberg \& Rosenberg, supra note 4, at 1027-41.

31. For works in English discussing the analysis presented by Maimonides, see KIRSCHENBAUM, supra note 4, at 62-68, and Rosenberg \& Rosenberg, supra note 4, at 1032-41.

32. See MAImONIDES, supra note 20, Laws of Sanhedrin 18:6. For a discussion of the implications of the term "scriptural decree" in this context, see Rosenberg \& Rosenberg, supra note 4, at 1033-34 n.284.

33. See, e.g., Numbers 35:30; Deuteronomy 17:6; Deuteronomy 19:15. For works in English analyzing Biblical sources for the prohibition against self-incrimination, see KIRSCHENBAUM, supra note 4, at 25-33, and Rosenberg \& Rosenberg, supra note 4, at 974-84.

34. See MAIMONIDES, supra note 20, Laws of Sanhedrin 18:6.

35. See supra notes $25-29$ and accompanying text. 
as the basis for punishment because of a concern that perhaps the defendant confessed out of a "confused mind" in the matter." Maimonides describes a form of extreme depression that results in suicidal tendencies; he explains that an individual suffering from such a condition may falsely confess to a capital offense for the purpose of being executed. ${ }^{37}$ Maimonides then concludes his discussion of the subject with a reminder that, regardless of any rationale identified and articulated by humans, the exclusion of self-incrimination remains a divine decree. ${ }^{38}$

Throughout his many works of law and philosophy, Maimonides developed groundbreaking frameworks for the analysis of nearly every area of Jewish thought. ${ }^{39}$ His discussion of self-incrimination has provided fertile ground for later commentators, perhaps most significant among them Rabbi David ben Zimra [Radbaz], who lived several centuries after Maimonides and authored an important commentary on the Mishne Torah. ${ }^{40}$ Like Maimonides, Radbaz states that the rule against selfincrimination is a divine decree; therefore, its inherent wisdom is

36. See MAIMONIDES, supra note 20, Laws of Sanhedrin 18:6.

37. See id. A number of scholars of Jewish law have offered alternative psychological explanations for the ban on self-incrimination, identifying ulterior motives that may induce a false confession. Professor Kirschenbaum has cited the following suggestions:

[An individual] may have been present at certain business transactions or ritual ceremonies, and now, summoned to testify..."confesses" to a sin which disqualifies [the individual from testifying as a witness] and thereby "escapes." A confession to having committed a minor violation may furnish ... an alibi for a major crime ... perpetrated. Ulterior motives may vary: from a desire to save a beloved friend from punishment to an attempt to obtain warm shelter and food in winter - the possibilities are limitless.

KIRSCHENBAUM, supra note 4, at 64-65.

38. See MAIMONIDES, supra note 20, Laws of Sanhedrin 18:6.

39. See ISADORE TWERSKY, INTRODUCTION TO THE CODE OF MAIMONIDES (MISHNEH TORAH) 1 (1980). Professor Twersky observed that

[Maimonides'] reputation needs no inflation or exaggeration, for his stature is nearly sui generis and his commanding influence has been almost universally recognized.... He wrote epoch-making works in the central areas of halaka and religious philosophy-an achievement that is unquestionably, almost overpoweringly, characterized by monumentality, using the term very literally. His works, representing an unprecedented conjunction of halakic authority and philosophic prestige, were extensively studied, meticulously annotated, frequently translated, and intensively interpreted. Their influence, direct as well as indirect, reflected through many works in various genres by a host of authors, was global.

40. For works in English analyzing the position of Radbaz, see KIRSCHENBAUM, supra note 4, at 72-77, and Rosenberg \& Rosenberg, supra note 4, at 1036-41. 
beyond question. ${ }^{41}$ Nevertheless, again like Maimonides, Radbaz engages in an attempt to understand the divine logic underlying the rule. ${ }^{42}$

Expounding upon, or perhaps adding to, the rationale that Maimonides proposes, Radbaz emphasizes a distinction between confessions: those that potentially result in capital or corporal punishment, which are excluded from evidence, and concessions to monetary obligation, which are admissible as evidence and bind the defendant to satisfy the obligation. ${ }^{43}$ Radbaz explains that in Jewish thought, human beings have legal authority over their physical possessions, including both the autonomy to give their possessions to others and, consequently, the authority to admit to and thereby obligate themselves in a monetary debt. ${ }^{44}$ In contrast, Jewish thought views both human life and the human body as sacred, to the extent that humans do not have legal autonomy to commit suicide or even harm their own bodies. ${ }^{45}$ Therefore, because human life remains within God's province, human beings may not offer a legally valid confession resulting in their lives being taken, or in another form of corporal or capital punishment. $^{46}$

As divine law is deemed eternally and universally binding on all segments of the Jewish nation, in any time or place, it is not uncommon for legal philosophers to seek philosophical or psychological lessons in the law which are particularly suitable to the societal context in which they live. Thus, for example, Rabbi Norman Lamm, later president of Yeshiva University, authored an influential 1956 article providing a decidedly modern

41. See Radbaz, Commentary, in MAIMONIDES, MISHNE TORAH, Laws of Sandedrin 18:6, supra note 20.

42. See id. See also supra notes $25-29$ and accompanying text.

43. See Radbaz, supra note 41.

44. See id.

45. See id. (quoting Ezekiel 18:4).

46. See id. Other scholars have offered alternative explanations for the different rules regarding criminal confessions and monetary admissions. "[B]y an admission, an obligation was created which had only to be enforced by the court; whereas the conviction of a criminal offence was not in the nature of the enforcement by the court of an obligation voluntarily undertaken by a party but of a creation by the court of the party's liability. Cohn, supra note 30, at 178 (quoting MORDECHAI EPSTEIN, LEVUSH MORDECHAI (19th Century). For further discussion of the differences in the nature of criminal and monetary obligation, see KIRSCHENBAUM, supra note 4, at 78-81; SCHACHTER, supra note 15, at 266-68; SCHACHTER, supra note 6, at 276. 
understanding of the theories of Maimonides and Radbaz. ${ }^{47}$ Observing that Maimonides premised his analysis on psychological considerations of suicidal tendencies, Rabbi Lamm asserts that Maimonides "anticipated by some seven hundred years, albeit in rudimentary fashion, a major achievement of psychoanalysis[,]" namely, Freud's theory of "Death Wish" or "Death Instinct." "In Freud's view, Rabbi Lamm explains, at a basic level the Death Wish "reveals itself generally as destructiveness, in its many varied forms, and, in extreme cases, in homicide." a variety of reasons, the Death Wish, originally felt toward others, is usually frustrated and as a result is redirected toward the self.",50 Finally, "[a]t times, therefore, this Death Wish when it reaches its ultimate expression and is redirected towards the self, appears as suicide." $"$ 11

Moreover, Rabbi Lamm finds a further analogue to modern psychoanalytical theory in the exclusion of self-incrimination in Jewish law in cases involving forms of corporal punishment other than capital punishment. Turning to the work of Karl Menninger, Rabbi Lamm notes that because the Death Instinct is usually only partially neutralized by the Life Instinct, the emerging tension produces not suicide, but "a variety of forms of partial or chronic self-destruction," including "self-injury and self-mutilation.,"52 Thus, Rabbi Lamm concludes, "[w]hile certainly not all, or even most criminal confessions are directly attributable, in whole or in part, to the Death Instinct, the Hala[c]ha is sufficiently concerned with the minority of instances, where such is the case, to disqualify all criminal confessions and to discard confession as a legal instrument." 53

\section{IV.APPLICATION TO THE AMERICAN LEGAL SYSTEM}

In light of the foregoing overview of the nature of halacha in

47. Norman Lamm, The Fifth Amendment and Its Equivalent in the Halakhah, 5 JUDAISM 53, 56 (1956).

48. Id. (citing SIGMUND FREUD, NEW INTRODUCTORY LECTURES ON PSYCHOANALYSIS 147 (W. W. Norton \& Co. 1965); SIGMUND FREUD, BEYOND THE Pleasure PRINCIPLE (W. W. Norton \& Co. 1961); Sigmund Freud, Mourning and Melancholia, in IV COLLECTED PAPERS 156 (Hogarth Press, London 1925).

49. Id.

50. Id.

51. Id.

52. Id. at 57 (citing KARL MENNINGER, MAN AGAINST HIMSELF 82 (1938)).

53. Id at 59 . 
general and the rule in Jewish law regarding self-incrimination in particular, it may be instructive to consider possible application to the American legal system. One perspective for analyzing this question might operate from within Jewish legal theory, accepting the inherent authority of Jewish law to prescribe rules for the proper administration of justice in contemporary American society. An attempt to resolve this question thereby involves the broader issue of the Noachide laws, which, under Jewish thought, comprise a legal system applicable to all of humanity. ${ }^{54}$

Although the overwhelming majority of material comprising the corpus of Jewish law addresses the legal obligations of the Jewish nation, the substance of the Noachide laws has occupied a prominent position in Jewish legal discussion from ancient times through the present. ${ }^{55}$ These discussions have resulted in a fairly extensive body of law detailing various rules and regulations governing a parallel legal system that differs in significant respects from the legal system applicable to the Jewish nation. Not surprisingly, however, as it remained largely academic throughout most of Jewish history, the legal literature dealing with Noachide law is not nearly as developed or comprehensive as that relating to the law that was actually practiced amongst the Jewish nation. In fact, in contrast to lengthy and wide-ranging considerations of the issue of self-incrimination within the Jewish legal system, the voluminous library of Jewish legal theory is largely bereft of discussions of the admissibility of confessions under Noachide law.

The most prominent source to present a decisive position on

54. Under Jewish legal theory, God commanded all of humanity, through Adam, to observe a universal legal system comprised of six basic laws. See KAPLAN, supra note 1, at 40. A seventh law was commanded to all of humanity through Noah, accounting for the appellation of the Noachide laws. See id. God then began to command additional laws, to Abraham, Isaac, Jacob, and their descendants, culminating in the Revelation at Mount Sinai, at which the Nation of Israel received, through Moses, all of the commandments that constitute the Jewish legal system. See id. at 45-62.

55. See, e.g., THE BABYloniAN TALMUD, Sanhedrin 56a-59b; MAIMONIDES, supra note 20, Laws of Kings, ch. 9-10; RABBI ZVI HIRSCH CHAJES, 1 KOL SIFREI MAHARITZ CHAYOS (Collected Works) 58-63 (1958) (Hebrew); YITZCHAK HUTNER, PACHAD YITZCHAK: SHAVUOTH 31-34 (1999). Moreover, a number of contemporary law professors have produced English works dedicated to discussions of Noachide law. See, e.g, J. DAVID BLEICH, Capital Punishment in the Noachide Code, in 2 CONTEMPORARY HALAKHIC PROBLEMS 341-67 (1983); Arnold N. Enker, Aspects of Interaction Between the Torah Law, the King's Law, and the Noahide Law in Jewish Criminal Law, 12 CARDOzo L. REV. 1137 (1991); Nahum Rakover, Jewish Law and the Noahide Obligation to Preserve Social Order, 12 CARDozo L. REV. 1073 (1991); Suzanne L. Stone, Sinaitic and Noahide Law: Legal Pluralism in Jewish Law, 12 CARDOZO L. REV. 1157 (1991). 
this issue appears to be the Medieval work, Sefer Ha-Chinuch, which declares that Noachide law does not preclude the use of confessions as a basis for criminal punishment. ${ }^{56}$ In the absence of a more definitive legal authority, however, a number of scholars have attempted to draw inferences from a variety of legal sources. ${ }^{57}$ Other scholars have relied on an analysis of the relevant legal considerations. For example, some discussions have centered on placing confessions in the context of the distinct rules of evidence that govern the Noachide legal system..$^{58}$ At least one scholar has proposed, through a rather complex line of reasoning, alternative resolutions of the issue corresponding to the differing rationales offered by Maimonides and Radbaz ${ }^{59}$ for the ban on selfincrimination in proceedings operating under the Jewish legal system. ${ }^{60}$ Perhaps ironically, according to this logic, although the various explanations offered for the preclusion of confessions in Jewish law seem to have little, if any, effect on the application of the rule in the Jewish legal system, ${ }^{61}$ they would have significant practical ramifications for determination of the Noachide law of criminal procedure. ${ }^{62}$ Ultimately, however, discussions of the issue of self-incrimination in Noachide law remain largely inconclusive. ${ }^{63}$

A different mode of analysis for considering the application of the Jewish law of self-incrimination to the American legal system might address the issue from within the perspective of American law. Under such an approach, it would seem the

56. See SefEr HA-ChINUCH 81, 273 (Chaim Dov Chavel ed., 1986). For an analysis of this position, see KIRSCHENBAUM, supra note 4, at 97-98. For a discussion of the authorship of the Sefer Ha-Chinuch, see CHAIM DOV CHAVEL, Editor's Introduction, in SEFER HA-CHINUCH, supra, at 5-7.

57. See BLEICH, supra note 55, at 347-48 \& nn.6-7 (citing efforts to draw inferences from such authoritative sources as the Biblical Book of Samuel and the Jerusalem Talmud); KIRSCHENBAUM, supra note 4, at 96-99 \& $179 \mathrm{nn} .8-16$.

58. See KIRSCHENBAUM, supra note 4, at 97-98, $179 \mathrm{nn} .13-15$.

59. See supra notes $31-46$ and accompanying text.

60. See YeChIEL YA'AKOV WEINBERG, 2 SERIDEI ESH 252 (1962), cited in BLEICH, supra note 55 , at 348 n.6.

61. See supra notes $20-26$ and accompanying text.

62. Professor Kirschenbaum has suggested that the alternative explanations of Maimonides and Radbaz may have practical legal ramifications in the Jewish legal system as well, in relation to the issue of disqualification of witnesses. See KIRSCHENBAUM, supra note 4 , at 75-77. However, as Kirschenbaum emphasizes, according to either explanation, "under no circumstances can [one] be punished, capitally or corporally, on the basis of [one's] own statements." Id. at 77.

63. See BLEICH, supra note 55, at 348 (describing "conflicting views with regard to the acceptance of a confession by Noachide courts"). 
substance and reasoning of Jewish law is relevant only to the extent that it is meaningful within the internal logic of American legal discourse. Consequently, this analysis would discount any suggestion that the American legal system should directly adopt the rule of self-incrimination found in the Jewish legal system, or any notion of the authority of Jewish law to prescribe binding rules of evidence for the American legal system. Instead, a conceptual approach to the application of Jewish law might motivate the rethinking and possible modification of the American law of confessions based on insights and lessons that arise out of an analysis of the Jewish law regarding self-incrimination. ${ }^{64}$

Significantly, numerous courts and scholars alike have turned to Jewish law to help inform the American law of selfincrimination, without advocating that the American legal system incorporate an outright ban on criminal confessions. ${ }^{65}$ Writing for

64. A conceptual approach to the role of Jewish law as a form of comparative law for the analysis of American law is consistent with the approach I have advocated elsewhere. See Samuel J. Levine, Capital Punishment and Religious Arguments: An Intermediate Approach, 9 WM. \& MARY BILL RTS. J. 179, 190 (2000) (describing "the possibility and utility of looking to religious thought, not as binding legal authority, but as a comparative law model deserving attention in the consideration of American legal issues"); Samuel J. Levine, Capital Punishment in Jewish Law and Its Application to the American Legal System: A Conceptual Overview, 29 ST. MARY's L.J. 1037, 1039 (1998) (focusing on "the conceptual underpinnings behind pertinent Jewish law, considering the potential relevance and effect of those conceptualizations on American legal thought"); Samuel J. Levine, Law, Ethics, and Religion in the Public Square: Principles of Restraint and Withdrawal, 83 MARQ. L. REV. 773, 780 (2000) (calling for "a consideration of the conceptual foundations underlying the approach [to a legal issue] in Jewish law, with the aim of identifying and applying those that are suitable to the American legal [system]"); Levine, Jewish Legal Theory, supra note 2, at 444 (stating that "conceptual similarities between American law and Jewish law allow for meaningful yet cautious comparison of the two systems").

See also Rosenberg \& Rosenberg, supra note 4, at 1041-42:

Comparative law is tricky. The danger (or absurdity) of trying to stuff a whale into a molted snakeskin is obvious. There is nonetheless an irresistible temptation to try to derive at least some insights form a legal system two thousand years old, that was quite advanced and sophisticated not only for its time, but for ours, and that some claim to be the source of the self-incrimination clause of the fifth amendment.

Both cultures faced head on the question of the appropriate stance for government with respect to inculpatory statements in criminal cases. On the surface, the United States and ancient Israel appear to have made dissimilar choices. Yet the two approaches are not unrelated, and their touch points can perhaps assist in analysis of contemporary law (internal citations omitted).

Cf. Randy Lee, A Look at God, Feminism, and Tort Law, 75 MARQ. L. REV. 369 (1992); Steven D. Smith, Legal Discourse and the De Facto Disestablishment, 81 MARQ. L. REV. 203 (1998).

65. See sources cited supra note 4. 
the United States Supreme Court in Miranda v. Arizona, ${ }^{66}$ the landmark case defining the contours of the constitutional privilege against self-incrimination, Chief Justice Warren quoted the view of Maimonides and referred to Rabbi Lamm's article. ${ }^{67}$ Less than one year later, addressing the concern of coercion in the context of self-incrimination, Justice Douglas included in the Court's majority opinion an extensive quotation from Rabbi Lamm's article. ${ }^{68}$ Likewise, a number of other courts, as well as scholars, have found in the Jewish legal system an illuminating antecedent for English and American laws providing protections against selfincrimination. ${ }^{69}$ Although some have questioned the existence of any direct historical connection between Jewish law and American law in this area, ${ }^{70}$ such objections should not preclude careful yet valuable conceptual comparison.

In fact, application of the reasoning behind categorical exclusion of criminal confessions in Jewish law does not imply mechanical imposition of a similar ban in American law. ${ }^{11}$ As many

66. Miranda v. Arizona, 384 U.S. 436 (1966).

67. Id. at 458 \& n.27 (citing MAIMONIDES, supra note 20, Laws of Sanhedrin 18:6; Lamm, supra note 47). Chief Justice Warren observed that the "roots [of the privilege against self-incrimination] go back into ancient times," and, quoting Maimonides, stated that "[t]hirteenth century commentators found an analogue to the privilege grounded in the Bible." Id.

68. See Garrity v. State of New Jersey, 385 U.S. 493, 497 n.5 (1967) (quoting Lamm, supra note 47).

69. See supra note 4.

70. See, e.g., Arnold Enker, Self-Incrimination, in JEWISH LAW AND CURRENT LEGAL PROBLEMS, supra note 4, at 169 (stating that "[t]he thesis of my presentation today will be that exaggerated claims have been and are being made for the sources of self-incrimination in Jewish law, and for the notion that important lessons can be learned from Jewish law with respect to self-incrimination"); KIRSCHENBAUM, supra note 4, at 1921; LEVY, supra note 4, at 439-40 (stating that "[w]hether the existence of the right against self-incrimination in Talmudic law in any way influenced the rise of the right in AngloAmerican law is an intriguing question" but concluding that "the answer, if based on evidence rather than speculation, must be negative"). But see Braz, supra note 4, at 162 (arguing that "Jewish law and Talmudic jurisprudence constitute one of the main streams that converged to form the unique common law doctrine against self-incrimination); Horowitz, supra note 4. See also Rosenberg \& Rosenberg, supra note 4, at 1042 n.310.

71. Moreover, although the ban on self-incrimination represents the normative standard prescribed by the Jewish legal system, in practice the system provided a license for deviation from this standard under exigent circumstances. See Enker, supra note 21, at cxxiii; Enker, supra note 69, at 1141-1147; HALBERSTAM, supra note 4, at 187; KIRSCHENBAUM, supra note 4, at 82-92, 135-36; Rosenberg \& Rosenberg, supra note 4, at 1018-27. These deviations would seemingly have to be acknowledged and addressed in any attempts to incorporate mechanically into American law the precise rule of selfincrimination found in Jewish law. Indeed, at least one scholar finds the existence of such deviations so significant as to preclude contemporary American relevance of the Jewish 
scholars have noted, an outright preclusion of self-incrimination would appear highly impractical in contemporary American society, as well as contrary to the internal logic and experience of the American legal system. ${ }^{72}$ Nevertheless, a thoughtful consideration of self-incrimination in Jewish law may lead to rethinking the treatment of confessions in American law to include a more subtle and nuanced definition and application of the basic concept of voluntariness. In light of the seemingly perennial problem of wrongfully obtained and even false confessions in the United States, ${ }^{73}$ it may be wise to incorporate some of the philosophical and psychological insights that scholars of Jewish law have offered into the nature of and possible motivations behind an admission of criminal conduct. ${ }^{74}$

law of self-incrimination. See Enker, supra note 21, at cxxiii. Nevertheless, the conceptual approach to the application of Jewish law to American law appears largely immune to such objections, as the analysis relies not upon the practical implementation of the rule in Jewish law but instead upon its conceptual articulation and its theoretical and philosophical underpinnings.

72. See, e.g., Enker, supra note 21, at cxxii (concluding that "the Jewish Law treating confessions is not particularly relevant to the [contemporary] confessions debate, primarily because the procedural and evidentiary premises of the Jewish legal system which developed these rules are so radically different from our own that the legal issues posed are equally different"); KIRSCHENBAUM, supra note 4, at 134-37 (stating that, for the rules of self-incrimination in Jewish law to "be used intelligently" in contemporary consideration of the issue, "certain factors must be mentioned and dealt with," including: "whether the fact that the Jewish ancients lived a rather uncomplicated life in smaller, relatively homogeneous groupings - both geographically and sociologically-allowed for features in their judicial system that may strike us as starry-eyed and impractical"; and "that the Rabbis believed sincerely that [humans] could not and [were] not commanded to solve all problems of law-enforcement" as "Divine Justice and Divine Retribution were realities in the world-view of the Rabbis," and thus "the liberal judicial procedure and heavy protection of the rights of the accused in Jewish law were coupled with a deep religious confidence that the criminal will eventually receive... just deserts and that justice will triumph"); Rosenberg \& Rosenberg, supra note 4, at 1042-46.

73. See, e.g., Steven A. Drizin \& Richard A. Leo, The Problem of False Confessions in the Post-DNA World, 82 N. C. L. REV. 891, 901-07 (2004) (citing Hugo Adam Bedau \& Michael L. Radelet, Miscarriages of Justice in Potentially Capital Cases, 40 STAN. L. REV. 21, 47, 49, 57 (1987); EDWARD CONNOR ET AL., CONVICTED BY JURIES, EXONERATED BY SCIENCE: CASE STUDIES IN THE USE OF DNA EVIDENCE TO ESTABLISH INNOCENCE AFTER TRIAL 15-17 (1996); Innocence Project, Case Profiles, at http://www.innocenceproject.org/case/index.php; BARRY SCHECK, PETER NEUfELD \& JIM DWYER, ACTUAL INNOCENCE (2000)).

74. In fact, on the basis of an examination of Jewish law, a number of American legal scholars have proposed and justified modifications to the American law of selfincrimination. See, e.g., Goldberg, supra note 4, at viii-ix (describing ways in which "[w]e have something to learn from this ancient tradition"); HALBERSTAM, supra note 4, at 18687 (suggesting that "perhaps, as the [American] privilege [against self-incrimination] approaches the absolute... [i]t must be justified, if at all, only morally, as in ancient 
Indeed, a leading contemporary study of false confessions in the American legal system describes two substantial factors contributing to the phenomenon of "interrogation-induced false confession." 75 The study identifies the primary factor as a complex process of "psychological manipulation" and "psychological coercion." A6 "Additionally, according to the study, "some individuals - particularly juveniles and the mentally retarded -are

Jewish law"); Rosenberg \& Rosenberg, supra note 4, at 1042-46:

The rock bottom teaching of the Talmud is that a unitary, per se exclusionary rule with respect to confessions is the preferred way to deal with this issue. In this country, we have no single, absolute rule; instead, various provision give piecemeal protection....

... Miranda's method is more tenuous because the very people responsible for obtaining evidence of crimes are also made responsible for assuring voluntariness. When judicial inroads and excisions are added to that inherent systemic weakness-inroads and excisions that tend to make the means as relative as the ultimate standard-there is a corresponding increase in the possibility of abusive police methods. The danger of a relative rule with respect to confessions is that one's starting point is already at, or near, the cusp, and any relaxation enhances the risk that resulting confessions will fall into the realm of involuntariness and perhaps unreliability.

Miranda is the bright line in American law, our functional equivalent of the Talmudic no-confessions rule.... Miranda's irrebuttable presumption was an attempt to confine the vagaries of relativity, and every modification of it resonates ominously. The more Miranda is devitalized, the greater and more reasonable the doubts as to voluntariness of confession in this country. This once bright line has become enshrouded with restrictive interpretations that form part of the rule and impede its essential purpose.

75. Drizin \& Leo, supra note 72 , at 919. See id. at 910-11 (stating that "[s]ocial scientists and legal scholars have amply documented that contemporary methods of psychological interrogation can, and sometimes do, lead innocent individuals to confess falsely to serious felony crimes") (citing GISLI GUDJONSSON, THE PSYCHOLOGY OF INTERROGATIONS AND CONFESSIONS 205-58 (2003); Saul Kassin, The Psychology of Confession Evidence, 52 AM. PSYCHOL. 221, 224-25 (1997); Richard A. Leo \& Richard J. Ofshe, The Consequences of False Confessions: Deprivations of Liberty and Miscarriages of Justice in the Age of Psychological Interrogations, 88 J. CRIM. L. \& CRIMINOLOGY 429, 440-49 (1988); Richard J. Ofshe \& Richard A. Leo, The Decision to Confess Falsely: Rational Choice and Irrational Action, 74 DEN. L. REV. 979, 981-1001 (1997) [hereinafter Ofshe \& Leo, Decision to Confess Falsely]; Richard A. Leo \& Richard J. Ofshe, The Social Psychology of Police Interrogations: The Theory and Classification of True and False Confessions, 16 STUD. L. POL. \& SOC'Y 189, 191-94 (1997)). See generally Drizen \& Leo, supra note 72, at 907-23 (2004).

76. Drizin \& Leo, supra note 72, at 914. See id. at 918 (characterizing “[m]odern psychological interrogation [as] a gradual yet cumulative process [in which] each technique builds on the next as the investigator seeks to emphasize the overriding strength of the State's case and the futility of the suspect's denials" and concluding that "[i]ntended for the guilty, modern interrogation techniques are psychologically powerful enough to elicit confessions from the innocent"). See generally id. at 914-19. See also Ofshe \& Leo, Decision to Confess Falsely, supra note 74, 76 passim. 
more vulnerable to the pressures of interrogation and are therefore less likely to possess or to be able to muster the psychological resources of perspective necessary to withstand accusatorial police questioning." "Th Such discussions of the role of psychological confusion as a cause of false confessions, including special attention to individuals of particular psychological vulnerability, echo - and, thus, may offer a trenchant illustration of the potentially illuminating application of - the psychological insights Maimonides and others offered in their analysis of the ban on confessions in Jewish law. ${ }^{78}$

\section{CONCLUSION}

The issue of self-incrimination has confronted AngloAmerican scholars and jurists for centuries, ${ }^{79}$ resulting in the adoption of the Fifth Amendment right against self-incrimination as a central tenet of American constitutional law. ${ }^{80}$ In the words that conclude a leading historical study of the subject, "[a]bove all, the Fifth Amendment reflected [the framers'] judgment that in a free society, based on respect for the individual, the determination of guilt or innocence by just procedures, in which the accused made no unwilling contribution to his conviction, was more important than punishing the guilty."

If this right is to continue to be taken seriously, the American legal system should acknowledge and work to protect against the variety of ways in which a seemingly voluntary confession may in fact be less than willful, or even the product of coercion, however subtle. $^{82}$ Conceptual consideration of the approach to self-

77. Drizin \& Leo, supra note 72, at 919 (citing Morgan Cloud et al., Words Without Meaning: The Constitution, Confessions, and Mentally Retarded Suspects, 69 U. CHI. L. REV. 495, 499-516 (2002); James W. Ellis \& Ruth A. Luckasson, Mentally Retarded Criminal Defendants, 53 GEO. WASH. L. REV. 414, 445-52 (1985); Paul Hourihan, Earl Washington's Confession: Mental Retardation and the Law of Confessions, 81 VA. L. REV. 1471, 1491-94 (1995), GUDJONSSON, supra note 74, at 285 (recommending the use of broad, general questions to avoid suggestibility and acquiescence)).

78. See supra notes 31-53 and accompanying text.

79. See Helmholz, supra note 4, at 279 n.28; LEVY, supra note 4.

80. See LEVY, supra note 4, at 405-32.

81. See id. at 432.

82. See supra notes 74-77 and accompanying text. Cf. Drizin \& Leo, supra note 74 , at 910 (finding that "[a]s psychological methods of interrogation have evolved over the years, they have become increasingly sophisticated, relying on more subtle forms of manipulation, deception, and coercion"); $i d$. at 918 (concluding that "[t]he primary psychological cause of most false confessions is ... the investigator's use of improper, 
incrimination in Jewish law may help facilitate such a reassessment of American law. As one scholar put it, "[w]hile there is no room in the contemporary system of proof for the absolute exclusion of confessions and guilty pleas, an increased sensitivity to their limitations as proof and the introduction of a requirement that the judge ascertain what other evidence exists to be weighed with the confession before entering the conviction would be a warranted lesson to learn from the Jewish Law." ${ }^{" 83}$

coercive interrogation techniques"); Rosenberg \& Rosenberg, supra note 4, at 1043-44 ("Inability to choose freely whether to assist the prosecution in securing one's own conviction- - no matter how reliable or ostensibly imperative that assistance may be- - is by any other name coercion."); Stephen J. Schulhofer, Miranda's Practical Effect: Substantial Benefits and Vanishingly Small Social Costs, 90 NW. L. REV. 500 (1996):

[W] hatever one may think of Miranda, it is clear-and uncontroversial-that pressure need not rise to the level of overbearing physical or psychological coercion, in the due process sense, before it is sufficiently compelling to violate the Fifth Amendment ... [A] formalistic showing of compulsion by legal process or official punishment cannot be essential.... Indeed, as the Miranda Court noted ... the "interrogation environment is created for no purpose other than to subjugate the individual to the will of his examiner." As a result, the typical custodial police interrogation, even if not brutally coercive in the due process sense, will readily (perhaps almost invariably) violate the Fifth Amendment bar on the use of compelling pressure, at least in the absence of safeguards sufficient to dispel that pressure.

Id. at 551-53 (quoting Miranda v. Arizona, 384 U.S. 436, 457 (1966)).

83. See Enker, supra note 21, at cxxiv. 
. 